\title{
Reaction sequence of blood coagulation
}

Citation for published version (APA):

Hemker, H. C., \& Kahn, M. J. P. (1967). Reaction sequence of blood coagulation. Nature, 215, 1201 1202. https://doi.org/10.1038/2151201a0

Document status and date:

Published: 01/01/1967

DOI:

10.1038/2151201a0

Document Version:

Publisher's PDF, also known as Version of record

\section{Please check the document version of this publication:}

- A submitted manuscript is the version of the article upon submission and before peer-review. There can be important differences between the submitted version and the official published version of record.

People interested in the research are advised to contact the author for the final version of the publication, or visit the DOI to the publisher's website.

- The final author version and the galley proof are versions of the publication after peer review.

- The final published version features the final layout of the paper including the volume, issue and page numbers.

Link to publication

\footnotetext{
General rights rights.

- You may freely distribute the URL identifying the publication in the public portal. please follow below link for the End User Agreement:

www.umlib.nl/taverne-license

Take down policy

If you believe that this document breaches copyright please contact us at:

repository@maastrichtuniversity.nl

providing details and we will investigate your claim.
}

Copyright and moral rights for the publications made accessible in the public portal are retained by the authors and/or other copyright owners and it is a condition of accessing publications that users recognise and abide by the legal requirements associated with these

- Users may download and print one copy of any publication from the public portal for the purpose of private study or research.

- You may not further distribute the material or use it for any profit-making activity or commercial gain

If the publication is distributed under the terms of Article $25 \mathrm{fa}$ of the Dutch Copyright Act, indicated by the "Taverne" license above, 


\section{Reaction Sequence of Blood Coagulation}

IN 1964 Macfarlane $^{1}$ proposed a reaction mechanism for the interaction of blood coagulation factors, known as the enzyme cascade. In this hypothesis the blood coagulation factors as they occur in plasma are considered to be zymogens (except factor I; namely, fibrinogen). Coagulation is initiated by the conversion of one of these zymogens into an enzymo as a result of contect with anything other than intact vascular ondothelium. This enzyme then acts on another clotting factor to form another active enzyme. All clotting factors thus interact in a given order until prothrombin (factor II) is converted into thrombin. Thrombin then brings about the actual coagulation by converting fibrinogen into fibrin.

The prothrombin converting activity (prothrombinase activity) was first thought to be exerted by activated factor $V$ (ref. 1). As the result of further work it now seems that the prothrombinase activity is displayed by a complex of activated factor $\mathbf{X}\left(f \cdot \mathbf{X}_{a}\right)$, calcium ions (II) and factor $\mathbf{V}(f . V)$ which are adsorbed together on a phospholipid surface.

The evidence for this concept is of two kinds. (a) It can be shown that $f . X_{a}$ and $f . V$ are bound by phospholipid micelles, and that calcium ions favour the binding
of $f . X_{a}$. High concentrations of calcium, however, inhibit $f . \mathbf{X}_{a}, f . V$, phospholipid and calcium ions cen be explained by assuming that a product of all four reactants is the f.II converting substance. It cannot be explained by $a$ reaction of the cascade type ${ }^{6}$.

This communication shows that evidence can also be provided for the existence of a complex consisting of the clotting factors IX (in activated form) and VIII, and phospholipid, similar to that described in section (a). The interaction between $f$. IX and $_{a}$.VIII previously has been considered to be of the cascade type, that is

$$
\mathrm{VIII} \stackrel{\mathrm{IX}_{a}}{-} \rightarrow \mathrm{VIII}_{a}
$$

The experiments described in Table 1, however, show a strong similarity between the characteristics of adsorption onto phospholipid of $f \cdot \mathbf{X}_{a}$ and $f \cdot \mathrm{IX}_{a}$, on the one hand, and of $f . V$ and $f$.VII, on the other. Calcium ions favour the adsorption of $f \cdot \mathbf{X}_{a}$ and $f . \mathrm{IX}_{a}$; excess calcium inhibits the adsorption of $f . V$ and $f$.VIII. Control experiments show that it is the phospholipid that adsorbs the clotting factors. The activity that disappeared from the super- 
natant could be recovered from the resuspended phospho. lipid sediment. No activity was recorded from the phospholipid in experiments in which no activity was adsorbed from the sample.

Table 1. ADsORPTION OF COAGULATION HACTORS BY PHOSPHOTIPIB Calcium ion conc. (mmolar)

\begin{tabular}{cccc}
\multicolumn{4}{c}{ Percentage of clotting factor adsorbed } \\
V & VIII & IX & X \\
60 & 58 & 27 & 38 \\
$<1$ & 41 & 45 & 60 \\
$<1$ & 3 & 68 & 76
\end{tabular}

The figures give the means of three different experiments. Fach coagulation factor determinaticn was carried out eight times. The material used as a source of $f . V$ and $f$.VIII was barium sulphate adsorbed bovine oralated plasma. For $f . I X_{\text {end }}$ an. $\mathrm{X}_{6}$ oxalated bovine serum was used as a source. To prevent active thrombin being formed from residual amounts of prothrombln, $5 \mathrm{mcg} / \mathrm{ml}$. hirudin was added. The phospholipid used was s supponsion of inosithin prepared by homogenizing the crude materisl in inis-HCl buffer 0.02 molar, pH 7.5 containing 0.14 molar $\mathrm{NaCl}$. The reaction mixture con. sisted of $0.9 \mathrm{ml}$. plasma cr serum, $0.4 \mathrm{ml}$. CaCl, aolution in $(r i s-\mathrm{HCl} 20$ mmolar pH 7.5; $0.4 \mathrm{ml}$. of a suspension of inoeithin $5 \mathrm{mg} / \mathrm{ml}$. Half the mixture wras centrifuged for $30 \mathrm{~min}$ at $100,000 \mathrm{~g}$ at $4^{\circ} \mathrm{C}$; in the supernatant the original concentration of phospholipid was restored. The other half of the mixture was stored at $4^{\circ} \mathrm{C}$ and served as a control. The conoentration of the clotting factors in the centrifuged sample was determined and expressed as a percentage of that in the control. The percentage adeorbed was calculated as the amount not recovered in the supermatant. Factor VIII and IX were estimated according to Veltkamp, factors $\mathbf{V}$ and $\mathbf{X}$ were estimated as described in ref. 10. The concentration of hirudin used did not interfere with the clotting factor determinations.

The role of phospholipid in the interaction of $f . I_{a}$ and $f$.VIII has so far remained obscure, although it has been proved that this role is a mandatory one?. Our experiments strongly suggest that phospholipid interacts with calcium ions, f.IX $a$ and $f$. VIII in a manner similar to the interaction of phospholipid, calcium, $f . \mathbf{X}_{a}$ and $f . V$. If this is true, the reaction equation of the interaction would be

$$
\underset{\mathrm{IX}_{a}+\mathrm{VIII}_{a}+\mathrm{Ca}_{a}-\text { phospholipid }- \text { VIII }(\text { complex } A)}{\longrightarrow}
$$

Theoretically, it is possible to obtain more evidence for the existence of complex $A$ by investigating the kinetics of the generation of $f . X$ converting activity from the purified factors IX $_{a}$ and VII, that is, by a procedure analogous to the experiments cited in section (b). Technical difficulties in obtaining the pure factors IX $_{a}$ and VIII as well as in the measuring of the conversion $f . \mathrm{X} \longrightarrow \longrightarrow \rightarrow \mathrm{X}_{a}$ seem to prevent this approach in the near future.

The fact that kinetic evidence obtained with impure systems has so far suggested that $f$.VIII is converted enzymatically by $f . \mathrm{IX}_{a}$ (ref. 8) remains disturbing. From the results of experiments on the kinetics of the interaction of factors $\mathbf{X}_{a}$ and $V$, it was evident that if only $a$ limited range of concentrations was investigated, the results obtained simulated that of an enzyme inter- 
action. If the experiments were carried over a wide range of concentrations then the stoichiometric interaction is suggested".

We have paid no attention to the form in which $f . V$ and $f$.VIII participate in the reactions. By this we do not mean to say that we suppose them to be in the unmodified form in which they occur in intact plasma.

The considerations presented here suggest the following scheme of the intrinsic reaction mechanism of blood
coagulation

$$
\begin{aligned}
& \mathrm{XII} \stackrel{\text { contact }}{\longrightarrow} \longrightarrow \mathrm{XII}_{a} ; \mathrm{XI} \stackrel{\mathrm{XII}_{a}}{\longrightarrow} \rightarrow \mathrm{XI}_{a} ; \mathrm{IX} \stackrel{\mathrm{XI}_{\alpha}}{\longrightarrow} \rightarrow \mathrm{IX}_{a} \\
& \mathrm{IX}_{a}+\mathrm{VIII}+\text { phospholipid }+\mathrm{Ca}^{++} \longrightarrow \longrightarrow \longrightarrow \operatorname{complex} A \\
& \mathbf{X} \stackrel{\text { complex } A}{\longrightarrow} \rightarrow \mathbf{X}_{a} \\
& \mathbf{X}_{a}+\mathbf{V}+\text { phospholipid }+\mathrm{Ca}^{++} \longrightarrow \longrightarrow \rightarrow \operatorname{complex} B \\
& \text { II } \stackrel{\text { complex } B}{\longrightarrow} \longrightarrow \text { thrombin }
\end{aligned}
$$

We thank the Netherlands Foundation for Chemical Research (SON) and the Netherlands Organization for the Advancement of Pure Research (ZWO) for support.

H. C. Hrimkrar

Laboratory of Coagulation Biochemistry

M. J. P. Katn

Haematology Section,

Department of Internal Medicine,

University Hospital,

Leyden.

Recelved May 10, 1967.

Macfarlane, R. G., Nature, 202, 498 (1964).

Cole, F. R., Koppel, J. L., and Olwin, J. H., Thromb. Diathes. Haemorrh.
suppl. 14, 431 (1965).

Esnouf, M. P., and Jobin, F., Thromb. Diathes. Haemorrh., suppl. 17, 103
(1965).

Jobin, F., and Esnouf, M. P., Biochem. J., 102, 666 (1967).

- Papahadjopoulos, D., and Hanahan, D. J., Biochim. Biophys. Acta, 00, 436
(1964).

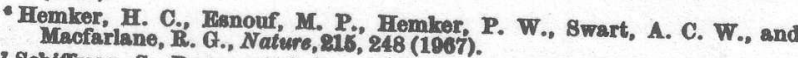

Bchifiman, 8., Rapaport, 8. I., and Chong, M. M. Y., Proe. Soc. Exp. Biol.
and Med., Ies, 736 (1966).

Biggs, Rosemary, and Macfarlane, R. A., Thromb. Diathes. Haemorrh.,
suppl. 17, 23 (1965).

- Hemker. J., Thromb. Diathes. Hacmorrh. (in the press, 1967). press, 1968). 